\title{
EVALUASI IMPLEMENTASI KTSP \\ PADA PEMBELAJARAN GEOGRAFI SMA \\ DI KOTA YOGYAKARTA
}

\author{
Mukminan \\ FISE Universitas Negeri Yogyakarta (e-mail: mukminan@yahoo.co.id; \\ HP: 08157956800)
}

\begin{abstract}
An Evaluation of the Implementation of the SBC in Geography Instruction in SHSs in Yogyakarta City. This study aims to describe the implementation of the School Based Curriculum (SBC) in geography instruction in senior high schools (SHSs) in Yogyakarta City in terms of teachers' dimension, consisting of instructional programs, instructional steps, and learning outcome assessment. It was an evaluation study employing a model by Stake by comparing the instructtional processes conducted by teachers with the appropriate criteria. The population comprised 56 geography teachers in 11 state SHSs and 41 private SHSs in Yogyakarta City. The sample was 30\% of the total schools selected by the school category (upper, middle, and lower) based on the results of the national assessment in geography in 2008. The data were collected through a questionnaire, observations, and documents and were analyzed using the qualitative descriptive technique. The findings show that the instructional programs, instructional steps, learning outcome assessment are in the good category.
\end{abstract}

Keywords: instructional programs, instructional steps, learning outcome assessment

\section{PENDAHULUAN}

Seiring perubahan yang terjadi dalam dunia pendidikan dan upaya implementasi Undang-Undang Nomor 20 Tahun 2003 tentang Sistem Pendidikan Nasional, khususnya terkait dengan Standar Nasional Pendidikan, pemerintah berusaha mewujudkan pengelolaan pendidikan yang semula bersifat sentralistik berubah menjadi desentralistik. Desentralisasi pengelolaan pendidikan ini memberikan kewenangan kepada satuan pendidikan (sekolah) untuk menyusun kurikulum yang lebih luwes. Pengembangan Kurikulum tersebut harus mengacu pada Standar Isi (SI), Stan- dar Kompetensi Lulusan (SKL), dan Pedoman Pelaksanaan SI dan SKL sebagaimana tertuang dalam Permendiknas Nomor 22, 23, dan 24 Tahun 2006.

Terkait dengan pengembangan kurikulum di Indonesia, Badrusalam (2007: 11) menggambarkan kebijakan pemerintah tentang kurikulum pendidikan menjadi masalah bagi guru, baik guru kelas maupun guru mata pelajaran di sekolah. Bukan hal yang mudah menentukan sikap ideal dalam menghadapi kebijakan pemerintah mengenai Kurikulum Tingkat Satuan Pendidikan (KTSP) sebagai kurikulum operasional yang disusun oleh sekolah mengacu 
pada standar isi yang ditetapkan oleh Badan Standar Nasional Pendidikan (BSNP) yang harus dilaksanakan oleh setiap satuan pendidikan berdasarkan potensi dan kebutuhan masing-masing. Dalam KTSP, pihak sekolah memiliki kewenangan membuat dan mengembangkan kurikulum. Konsekuensinya, para guru harus aktif dan kreatif dalam menentukan langkah-langkah pembuatan dan pengembangan kurikulum tersebut. Guru berhak sepenuhnya menentukan penilaian kepada peserta didik, bukan pihak-pihak yang tidak tahu tentang kualitas kemampuan peserta didik (student's skill quality). KTSP dapat dilaksanakan dengan baik dalam pembelajaran, hanya jika guru memiliki kompetensi dan profesional di bidangnya. Dalam KTSP, guru diharuskan memiliki kemampuan membuat program pembelajaran yang lebih kontekstual dengan keadaan setempat dan menguasai sistematika pembelajaran serta memiliki kemampuan penilaian dalam proses pembelajaran.

KTSP yang mulai diluncurkan pada bulan Mei 2006 oleh Menteri Pendidikan Nasional, secara nasional harus sudah dilaksanakan paling lambat tahun ajaran 2009/2010. Evaluasi terhadap implementasi KTSP dilakukan sebagai bentuk kontribusi terhadap dunia pendidikan.

Geografi merupakan salah satu mata pelajaran yang diatur dalam Permendiknas Nomor 22 Tahun 2006 yang diberikan pada jenjang SMA. Mata pelajaran ini disusun secara sistematis, komprehensif, dan terpadu dalam proses pembelajaran menuju kedewasaan dan keberhasilan dalam kehidupan di masyarakat. Pendekatan tersebut diharapkan akan memberikan pemahaman yang lebih luas dan mendalam pada bidang ilmu yang berkaitan dengan peserta didik. Setiap mata pelajaran tentu memiliki kekhasan yang membedakan mata pelajaran geografi dari mata pelajaran yang lain. Geografi mengkaji seperangkat peristiwa, fakta, konsep, dan generalisasi yang berkaitan dengan isu sosial. Menurut Doreen Massey dalam Royal Geographical Society (2010) dinyatakan bahwa:

"Geography is the study of the earth's landscapes, peoples, places and environments. It is, quite simply, about the world in which we live. Geography is unique in bridging the social sciences (human geography) with the natural sciences (physical geography). Geography puts this understanding of social and physical processes within the context of places and regions - recognising the great differences in cultures, political systems, economies, landscapes and environments across the world, and the links between them. Understanding the causes of differences and inequalities between places and social groups underlie much of the newer developments in human geography. Geography provides an ideal framework for relating other fields of knowledge. It is not surprising that those trained as geographers often contribute substantially to the applied management of resources and environments."

Tujuan pembelajaran geografi sebagaimana dimuat dalam Permendiknas Nomor 22 Tahun 2006, yaitu (1) memahami pola spasial, lingkungan dan kewilayahan serta proses yang berkaitan; (2) menguasai keterampilan dasar dalam memperoleh data dan informasi, mengkomunikasikan dan menerapkan pengetahuan geografi; (3) me- 
nampilkan perilaku peduli terhadap lingkungan hidup dan memanfaatkan sumber daya alam secara arif serta memiliki toleransi terhadap keragaman budaya masyarakat. Standar Kompetensi dan Kompetensi Dasar mata pelajaran geografi SMA bertujuan menjadi pendukung dalam mengembangkan potensi peserta didik agar peka terhadap masalah sosial yang terjadi di masyarakat, memiliki sikap mental positif terhadap perbaikan segala ketimpangan yang terjadi, dan terampil mengatasi setiap masalah yang terjadi seharihari,baik yang menimpa dirinya sendiri maupun yang menimpa kehidupan masyarakat. Dalam upaya mencapai pembelajaran yang optimal termasuk pelajaran geografi, menurut Sanjaya (2009: 167)harus mempertimbangkan beberapa hal di antaranya (1) kesesuaian dengan kompetensi yang akan dicapai; (2) kesesuaian dengan materi pelajaran; (3) ketersediaan sumber belajar; dan (4) pengalaman belajar harus sesuai dengan karakteristik siswa.

Pencapaian tujuan pendidikan antara daerah satu dengan daerah lainnya seringkali memiliki batasan dan situasi yang berbeda-beda, disesuaikan dengan keadaan daerah yang bersangkutan. Beberapa wilayah yang ada di Daerah Istimewa Yogyakarta (DIY) saat ini berupaya untuk lebih meningkatkan peran dunia pendidikan sebagai dasar awal peningkatan mutu sumber daya manusia. Salah satu wilayahnya adalah Kota Yogyakarta. Dalam bidang pendidikan, Kota Yogyakarta menjadi ujung tombak kemajuan dalam bidang pendidikan di provinsi DIY, bahkan pada tataran nasional. Namun demikian, bukan berarti kota ini telah mencapai suatu bentuk ideal sesuai harapan pendidikan nasional. Seiring perubahan dalam dunia pendidikan yang menuntut adanya peningkatan mutu sumber daya manusia, Kota Yogyakarta terus berbenah diri terkait dengan berbagai persoalan pendidikan. Salah satu yang menjadi perhatian adalah upaya peningkatan mutu pendidikan menuju pendidikan yang bermutu sesuai tujuan pendidikan nasional, terlebih tujuan pendidikan di provinsi DIY. Banyak faktor yang mempengaruhi keadaan tersebut, antara lain mutu guru, sarana dan prasarana yang ada, manajemen pendidikan dan peran serta masyarakat di samping kebijakan pemeritah.

Kota Yogyakarta telah melaksanakan KTSP pada sekolah-sekolah di wilayahnya, termasuk mengimplementasikan dalam pembelajaran geografi. Namun, kenyataan masih ada guru geografi SMA, baik negeri maupun swasta belum mampu mencapai kompetensi dan keprofesionalan yang memadai dalam mengajar. Keadaan tersebut dikhawatirkan akan berpengaruh pada hasil pembelajaran yang tidak sesuai dengan target dan aturan yang ada dalam KTSP. Sekolah negeri dengan fasilitas relatif memadai dan input peserta didik yang terpilih semestinya dapat menunjukkan hasil yang lebih baik dibandingkan sekolah swasta dengan fasilitas terbatas. Berkaitan dengan fenomena tersebut, dirasa penting melakukan evaluasi implementasi KTSP pada pembelajaran geografi SMA di Kota Yogyakarta sebagai bagian dari kemampuan guru profesional. Penelitian ini merupakan penelitian evaluasi, 
khususnya tentang implementasi KTSP pada pembelajaran geografi SMA di Kota Yogyakarta ditinjau dari dimensi guru.

Menurut Worthen danSanders (1981: 19), evaluasi didefinisikan sebagai:

"Evaluation is the determination of the worth of a thing. It includes obtaining information for use in judging the worth of a program, product, procedure, or objective, or of the potential utility of alternative approaches designed to attain specified objectives."

Kaufmann dan Thomas (1980:9)menjelaskan evaluasi sebagai proses yang membantu sesuatu menjadi lebih baik melalui identifikasi dan dokumentasi beberapa perbedaanhasil kegiatan masa lalu dan sekarang untuk menafsir apa yang akan dilakukan berikutnya. Stufflebeam dan Shinkfield (1985:159) merumuskan evaluasi sebagai suatu proses mendeskripsikan, mengumpulkan, dan menyajikan deskriptif dan informasi yang menentukan nilai dan manfaat beberapa tujuan objek, desain, implementasi dan dampak yang berguna untuk membuat keputusan, menyajikan keperluan-keperluan untuk pertanggung jawaban dan mempromosikan pemahaman terhadap fenomena yang terlibat. Sementara menurut Brinkerhoff, (1983:1-6) menyatakan bahwa evaluasi sebagai proses yang menentukan sejauh mana tujuan sebuah program dapat dicapai.

Evaluasi dapat terlaksana apabila dilakukan menggunakan model yang sesuai dengan konteks dan kompetensi yang harus dicapai. Dipertegas Kaufman \& Thomas (1980: 141) "...it is useful, however only when there is a decision to continue, modify, or stop a program, or activity." Model evaluasi sangat berguna dalam membantu pengambilan data sebagai bahan pembuatan keputusan, evaluasi juga dapat digunakan untuk pengambilan keputusan apakah dilanjutkan, berhenti, atau dilakukan modifikasi. Salah satu model yang digunakan pada penelitian ini yaitu model evaluasi dari Stake. Model Stake (Stake's countenance model of evaluation) ini terkonsentrasi pada dua langkah pekerjaan evaluasi yaitu deskripsi dan pertimbangan. Stake menekankan adanya pelaksanaan dua hal pokok yaitu: (1) deskripsi (description); (2) pertimbangan (judgements), serta membedakan adanya tiga tahap dalam evaluasi program yaitu: (1) input (antecedent); (2) proses (transaction); (3) hasil (outcomes).

Kaufman (1980:125-126) mengemukakan bahwa fase pendahuluan (antecendent phase) adalah tahap atau periode sebelum program dilaksanakan. Fase kedua, transaksi (transactional phase), adalah tahap dimana program diterapkan. Fase ketiga, hasil (outcomes phase) yaitu pengukuran hasil setelah seluruh program selesai dilaksanakan. Dalam membuat suatu judgment, evaluator mendasarkan pada duahal, yaitu:(1) standar yang ideal (absolute standard) lebih menjelaskan pada posisi program yang telah terealisasi sedangkan standar relatif (relative standard) menekankan pada suatu standar/kriteria yang diinginkan terjadi. Hal yang sangat penting dalam hal ini adalah bagaimana menghubungkan antara intens-observations-standardsjudgments dan antecedent, transactions dan outcomes. Kaitannya dengan kesesuaian (congruence) antara yang diharapkan (intended) dengan yang diamati 
(observed) pada evaluasi program pendidikan. Kaufman juga menekankan bahwa yang penting pada model Stake ini terletak pada evaluator yang membuat penilaian tentang program.

Memperhatikan uraian di atas, penelitian evaluasi ini menggunakan model Stake yang bertujuan untuk mendapatkan gambaran utuh tentang implementasi KTSP pada pembelajaran geografi SMA di Kota Yogyakarta, yang meliputi: (1) program pembelajaran berupa gambaran tentang perencanaan/ program pembelajaran geografi, yaitu perangkat pembelajaran; (2) sistematika pelaksanaan pembelajaran geografi berupa gambaran tahapan pelaksanaan kegiatan pembelajaran meliputi tahapan pendahuluan, kegiatan inti, dan tahapan penutup pembelajaran; dan (3) pelaksanaan penilaian pembelajaran yang disesuaikan dengan Permendiknas No. 20/2007 tentang Standar Penilaian Pendidikan.

Dalam konteks keilmuan, penelitian ini diharapkan dapat menjadi wahana untuk konfirmasi terhadap perubahan nyata terhadap paradigma baru pendidikan. Bagi para cendekiawan, hasil penelitian ini dapat dijadikan sebagai rujukan untuk merekayasa konsep pendidikan yang lebih baik di masa yang akan datang. Secara praktis bagi guru, hasil penelitian ini diharapkan dapat membantu mereka, khususnya guru geografi SMA di Kota Yogyakarta dalam meningkatkan mutu serta perannya dalam mewujudkan tujuan pendidikan nasional.

\section{METODE}

Penelitian ini merupakan penelitian yang evaluasi menggunakan model Stake dengan pendekatan deskriptif. Evaluasi model Stake dilakukan dengan membandingkan antara proses pembelajaran yang terjadi di lapangan (absolute standard) dengan proses pembelajaran yang seharusnya sebagai ukuran untuk menentukan keberhasilan. Pendekatan evaluasi model Stake menekankan adanya pelaksanaan dua hal pokok, yaitu melakukan penggambaran (description) dan pertimbangan (judgments). Dua hal pokok ini diperoleh melalui gambaran tahapan evaluasi, yaitu (1) input (antecedent); (2) proses (transaction); dan (3) hasil (out comes). Berdasarkan ketiga tahapan tersebut, peneliti membuat suatu pertimbangan (judgment) terkait dengan implementasi KTSP pada pembelajaran geografi SMA di Kota Yogyakarta ditinjau dari dimensi guru. Peneliti mendasarkan pada dua hal, yaitu: (1) standar yang ideal (absolute standard), yaitu menjelaskan pada proses pembelajaran yang telah terealisasi; dan (2) standar relatif (relative standard), yaitu mendasarkan pada suatu standar/kriteria yang diinginkan sesuai dengan tuntutan Kurikulum Tingkat Satuan Pendidikan (KTSP). Dalam pelaksanaannya, peneliti menghubungkan kaitannya dengan kesesuaian (congruence) antara yang diharapkan (intended) KTSP dengan yang teramati (observed).

Populasi penelitian ini adalah guru geografi SMA di Kota Yogyakarta yang berjumlah 56 orang yang tersebar ke dalam 11 SMA negeri dan 41 SMA swasta. Sampel diambil $30 \%$ dari masing-masing kelas atas, tengah, dan 
bawah yang dibentuk berdasarkan perolehan rata-rata hasil Ujian Nasional (UN) pada mata pelajaran Geografi tahun 2008 pada setiap sekolah. Pada setiap sekolah sampel diambil satu orang guru geografi. Hasil rata-rata UN untuk mata pelajaran Geografi tertinggi yaitu 8,9 dan terendah 4,01 sehingga interval kelasnya adalah $(8,9-4,01) \beta=$ 1,63. Hasil perhitungan interval kelas disajikan pada Tabel 1.

Tabel 1. Interval Kelas Sampel Penelitian

\begin{tabular}{ccccc}
\hline No & Interval & Kriteria kelas & Jml SMA & Sampel (30\%) \\
\hline 1 & $>7,27$ & Atas & 7 & $2,1(2$ sekolah) \\
2 & $5,64-7,26$ & Tengah & 31 & 9,3 (9 sekolah) \\
3 & $<5,64$ & Bawah & 14 & 4,2 (4 sekolah) \\
& Jumlah & & 52 & \\
\hline
\end{tabular}

Hasil perhitungan di atas diperoleh sampel 15 orang guru yang tersebar pada 15 sekolah sampel. Masing-masing sampel yang ditetapkan diperoleh secara acak sederhana (simple random) dengan pertimbangan bahwa setiap guru pada masing-masing sekolah sampel memiliki kesamaan (homogen) pada kelasnya.

Teknik pengumpulan data yang digunakan dalam penelitian ini adalah angket, observasi dan dokumentasi yang disesuaikan dengan langkah dari evaluasi model Stake. Pada fase pendahuluan (antecedent phase), akan digunakan teknik angket untuk memperoleh data kesiapan para guru geografi dalam melaksanakan proses pembelajaran di kelas. Hal ini ditunjukkan oleh kemampuanmereka. Pertama, memahami konsepkonsep pembuatan program pembelajaran meliputi pembuatan silabus dan Rencana Pelaksanaan Pembelajaran (RPP). Kedua, memahami konsep-konsep dalam sistematika pembelajaran, yaitu mengetahui cara menentukan tahapan pendahuluan, kegiatan inti, dan kegiatan penutup dalam pembelajaran.
Ketiga, memahami konsep pelaksanaan penilaian dalam pembelajaran sesuai dengan Permendiknas No. 20/2007 yang meliputi 9 kegiatan penilaian. Fase proses/penerapan (transaction phase) dideskripsikan penerapan program-program pembelajaran yang dilakukan oleh guru geografi melalui observasi langsung dalam proses pembelajaran di kelas. Fase terakhir, yaitu fase hasil program (outcome phase) dilakukan pengukuran setelah program dilaksanakan. Kriteria yang menunjukkan hasil ini digambarkan melalui deskripsi dari hasil angket dan observasi pada guru, serta dokumen-dokumen yang dimiliki guru geografi.

Semua data yang dikumpulkan melalui angket, observasi, dan dokumentasi dianalisis dengan menggunakan teknik analisis persentase (\%), kemudian dideskripsikan dan diambil kesimpulan tentang masing-masing komponen atas dasar kriteria yang telah ditentukan. Data variabel yang diperoleh dari hasil pengukuran diuraikan secara kuantitatif dan diklasifikasikan menjadi beberapa kategori sangat baik, baik, 
kurang baik, dan tidak baik. Berkenaan dengan keperluan tersebut digunakan skor rerata ideal (Mi) dan skor simpangan baku ideal (SBi) sebagai kriterianya. Tingkat kecenderungan dibagi dalam empat kategori sebagai berikut.

$$
\begin{array}{lll}
> & >(\mathrm{Mi}+1,5 \mathrm{SBi}) & : \text { sangat baik } \\
> & >\mathrm{Mi}-(\mathrm{Mi}+1,5 \mathrm{SBi}) & : \text { baik } \\
> & (\mathrm{Mi}-1,5 \mathrm{SBi})-\mathrm{Mi} & : \text { kurang baik } \\
><(\mathrm{Mi}-1,5 \mathrm{SBi}) & \text { : tidak baik }
\end{array}
$$

Penentuan jarak 1,5 SB untuk kategori ini dimaksudkan agar jarak kategori tidak terlalu kecil yang menjadikan kategori lebih banyak dan tidak terlalu lebar yang menjadikan kategori terlalu sedikit. Hal ini didasarkan pada distribusi normal yang terbagi enam bagian atau enam deviasi standar. Interval kategori variabel didasarkan pada skor tertinggi dan skor terendah dari masing-masing variabel penelitian. Selanjutnya, dicari skor rerata ideal (Mi) dan skor simpangan baku ideal (SBi) dengan menggunakan formula sebagai berikut.

> $\mathrm{Mi}=1 / 2$ (skor tertinggi + skor terendah)

$\mathrm{Sbi}=1 / 6$ (skor tertinggi - skor terendah).

Skor tertinggi ideal adalah skor tertinggi yang mungkin diperoleh subjek penelitian dari keseluruhan alternatif jawaban. Skor terendah ideal adalah skor terendah yang mungkin diperoleh subjek penelitian dari keseluruhan alternatif jawaban. Perhitungan skor tertinggi, terendah, Mi, dan Sbi. Berdasarkan kriteria di atas, disusun standar skor kategori kecenderungan variabel dan indikator variabel penelitian, yaitu dengan kategori sangat baik, baik, kurang baik, dan tidak baik.

\section{HASIL}

Berdasarkan tahapan evaluasi model Stake, diperoleh data sebagai berikut.

\section{FasePendahuluan (Antecedent Phase)}

Pada tahapan ini, dideskripsikan pemahaman guru geografi dalam melaksanakan proses pembelajaran di kelas. Pertama, memahami konsep-konsep pembuatan program pembelajaran meliputi pembuatan silabus dan rencana pelaksanaan pembelajaran (RPP). Kedua, memahami konsep-konsep dalam sistematika pembelajaran, yaitu mengetahui cara menentukan tahapan pendahuluan, kegiatan inti, dan kegiatan penutup dalam pembelajaran. Ketiga, memahami konsep pelaksanaan penilaian dalam pembelajaran sesuai dengan Permendiknas No. 20/2007 yang meliputi 9 kegiatan penilaian.

Tingkat pemahaman para guru geografi tentang pelaksanaan proses pembelajaran geografi yang diperoleh melalui angket ditampilkan dalam Tabel 2.

Tabel 2 menunjukkan bahwa hampir semua guru memahami proses pembelajaran geografi yang meliputi pembuatan program pembelajaran, sistematika pembelajaran, dan penilaian hasil belajar. Persentase perolehan penelitian menunjukkan angka lebih dari 86 persen guru memahaminya. Tingkat pemahaman para guru ini kemudian dikonfirmasi melalui fase berikutnya me-nurut model Stake, yaitu fase penerapan. 
Tabel 2. Ringkasan Umum Tingkat Pemahaman Guru terhadap Proses Pembelajaran Geografi

\begin{tabular}{llccc}
\hline No & Variabel & Kategori & Frekuensi & Persentase \\
\hline 1 & Program pembelajaran & Sangat baik & 1 & 6,67 \\
& & Baik & 12 & 80 \\
& & Kurang baik & 2 & 13,3 \\
2 & Sistematika pembelajaran & Baik & 15 & 100 \\
3 & Penilaian hasil belajar & Baik & 15 & 100 \\
\hline
\end{tabular}

\section{Fase Penerapan (Transaction Phase)}

Fase ini merupakan tahapan program diterapkan. Penerapan programprogram pembelajaran yang dilakukan oleh guru geografi melalui pengamatan langsung dalam proses pembelajaran dideskripsikan sebagai berikut.

\section{- Variabel Program Pembelajaran}

Berdasarkan analisis statistik, data variabel pelaksanaan program pembelajaran geografi SMA di Kota
Yogyakarta memiliki skor antara 192 sampai 258. Rerata variabel ini sebesar 217,13. Berpedoman pada kategori yang telah dibuat sesuai dengan teknik analisis data, rerata variabel program pembelajaran terletak pada interval 197,5-256,75, yang termasuk dalam kategori baik. Distribusi frekuensi perolehan skor kecenderungan variabel program pembelajaran disajikan pada Tabel 3.

\section{Tabel 3. Distribusi Frekuensi Perolehan Skor Kecenderungan Program Pembelajaran}

\begin{tabular}{ccccc}
\hline No. & Interval & Kategori & Frekuensi & Frekuensi Relatif $(\%)$ \\
\hline 1. & $>256,75$ & Sangat Baik & 1 & 6,67 \\
2. & $197,5-256,75$ & Baik & 12 & 80 \\
3. & $138,25-197,49$ & Kurang Baik & 2 & 13,33 \\
4. & $<138,25$ & Tidak Baik & 0 & 0 \\
& Jumlah & & 15 & 100 \\
\hline
\end{tabular}

Berdasarkan Tabel 3, dapat diketahui bahwa 6,67\% guru-guru geografi SMA di Kota Yogyakarta melaksanakan program pembelajaran dengan kategori sangat baik, sebagian besar yaitu $80 \%$ dalam kategori baik, 13,33\% dalam kategori kurang baik dan tidak ada yang termasuk dalam kategori tidak baik. Hal ini menunjukkan bahwa secara umum guru-guru geografi SMA di Kota Yogyakarta termasuk dalam ka- tegori baik dalam memahami dan melaksanakan program pembelajaran di sekolah yang meliputi indikator membuat perangkat pembelajaran, menentukan tujuan pendidikan satuan pendidikan, menentukan struktur dan muatan kurikulum, kalender pendidikan, silabus, dan merumuskan Rencana Pelaksanaan Pembelajaran (RPP) yang ditunjukkan oleh persentase terbesar perolehan skor tersebut. 
- Variabel Pelaksanaan Sistematika Pembelajaran

Berdasarkan analisis statistik, data variabel sistematika pembelajaran geografi SMA di Kota Yogyakarta memiliki skor antara 61 sampai 74 . Rerata variabel ini sebesar 66,33. Berpedoman pada kategori, rerata variabel sistematika pembelajaran terletak pada interval 62,5 - 81,25, termasuk dalam kategori baik. Distribusi frekuensi perolehan skor kecenderungan variabel sistematika pembelajaran disajikan pada Tabel 4 .

Tabel 4. Distribusi Frekuensi Perolehan Skor Variabel Sistematika Pembelajaran

\begin{tabular}{ccccc}
\hline No. & Interval & Kategori & Frekuensi & Frekuensi Relatif (\%) \\
\hline 1. & $>81,25$ & Sangat Baik & 0 & 0 \\
2. & $62,5-81,25$ & Baik & 12 & 80 \\
3. & $43,75-62,49$ & Kurang Baik & 3 & 20 \\
4. & $<43,75$ & Tidak Baik & 0 & 0 \\
& Jumlah & & 15 & 100 \\
\hline
\end{tabular}

Distribusi frekuensi perolehan skor kecenderungan variabel sistematika pembelajaran diketahui sebagian besar, yaitu $80 \%$ guru-guru geografi SMA di Kota Yogyakarta melaksanakan dan memahami sistematika pembelajaran dalam kategori baik, sedangkan kategori kurang baik $20 \%$, serta tidak ada yang termasuk kategori tidak baik. Hal ini menunjukkan bahwa secara umum pelaksanaan sistematika pembelajaran oleh guru-guru geografi SMA di Kota Yogyakarta termasuk dalam kategori baik. Indikator variabel ini meliputi proses pembelajaran pada tahapan pendahuluan, tahapan kegiatan inti, dan tahapan penutup.
- Variabel Penilaian dalam Pembelajaran

Berdasarkan analisis statistik, data variabel penilaian program pembelajaran geografi SMA di Kota Yogyakarta memiliki skor antara 144 sampai 166. Rerata variabel ini sebesar 151,73. Merujuk pada kategori, rerata variabel Penilaian pembelajaran terletak pada interval 135 - 175,5 termasuk dalam kategori baik. Distribusi frekuensi perolehan skor kecenderungan variabel penilaian pembelajaran disajikan pada Tabel 5.

Tabel 5. Distribusi Frekuensi Perolehan Skor Variabel Penilaian Pembelajaran

\begin{tabular}{ccccc}
\hline No. & Interval & Kategori & Frekuensi & Frekuensi Relatif $(\%)$ \\
\hline 1. & $>175,5$ & Sangat Baik & 0 & 0 \\
2. & $135-175,5$ & Baik & 15 & 100 \\
3. & $94,5-134,9$ & Kurang Baik & 0 & 0 \\
4. & $<94,5$ & Tidak Baik & 0 & 0 \\
& Jumlah & & 15 & 10 \\
\hline
\end{tabular}


Distribusi frekuensi perolehan skor kecenderungan variabel penilaian pembelajaran diketahui semua guru sudah melaksanakan secara baik. Hal ini menunjukkan bahwa secara umum sistem penilaian yaang digunakan oleh guru sudah sesuai dengan Permendiknas No. 20/2007 yang didasarkan atas pelaksanaan prinsip, teknik, instrumen, dan mekansime atau prosedur penilaiannya.

\section{Fase Hasil Program (Outcome Phase)}

Pada fase ini, dilakukan pengukuran hasil setelah program dilaksanakan yang diteliti pada tahap pertama dan kedua. Kriteria yang menunjukkan hasil ini digambarkan melalui deskripsi angket, observasi, dan dokumentasi pada guru geografi. Instrumen angket digunakan untuk menggambarkan distribusi jawaban pada setiap variabel.
Skor terendah dan tertinggi intrumen angket untuk masing-masing variabel adalah; (1) program pembelajaran (78 dan 312); (2) sistematika pembelajaran (22 dan 88); dan (3) pelaksanaan penilaian (37 dan 148). Instrumen observasi digunakan untuk menggambarkan variabel sistematika pembelajaran dengan skor terendah dan tertinggi, yaitu 3 dan 12. Instrumen dokumentasi digunakan untuk menggambarkan variabel program pembelajaran dan pelaksanaan penilaian dengan penilaian skor terendah dan tertinggi, yaitu $1 ; 4$ untuk variabel program pembelajaran dan 17 ; 68 untuk variabel pelaksanaan penilaian. Gambaran distribusi perolehan jawaban pada setiap variabel ditunjukkan pada Tabel 6.

Tabel 6. Distribusi Jawaban pada Setiap Variabel

\begin{tabular}{|c|c|c|c|c|c|c|c|c|c|c|c|c|c|}
\hline \multirow{3}{*}{$\begin{array}{c}\text { Nomor } \\
\text { Res- } \\
\text { ponden }\end{array}$} & \multicolumn{9}{|c|}{ Variabel } & \multirow{2}{*}{\multicolumn{3}{|c|}{ Jumlah }} & \multirow{3}{*}{ Total } \\
\hline & \multicolumn{3}{|c|}{$\begin{array}{c}\text { Program } \\
\text { Pembelajaran }\end{array}$} & \multicolumn{3}{|c|}{$\begin{array}{c}\text { Sistematika } \\
\text { Pembelajaran }\end{array}$} & \multicolumn{3}{|c|}{$\begin{array}{c}\text { Penilaian Hasil } \\
\text { Belajar }\end{array}$} & & & & \\
\hline & A & $\mathrm{D}$ & $\mathrm{Jml}$ & A & $\mathrm{O}$ & $\mathrm{Jml}$ & A & $\mathrm{D}$ & $\mathrm{Jml}$ & A & $\mathrm{O}$ & $\mathrm{D}$ & \\
\hline 1 & 255 & 3 & 258 & 66 & 8 & 74 & 117 & 49 & 166 & 438 & 8 & 52 & 498 \\
\hline 2 & 245 & 3 & 248 & 65 & 8 & 73 & 115 & 47 & 162 & 425 & 8 & 50 & 483 \\
\hline 3 & 233 & 3 & 236 & 66 & 7 & 73 & 111 & 48 & 159 & 410 & 7 & 51 & 468 \\
\hline 4 & 225 & 4 & 229 & 62 & 7 & 69 & 109 & 44 & 153 & 396 & 7 & 48 & 451 \\
\hline 5 & 227 & 4 & 231 & 63 & 6 & 69 & 109 & 45 & 154 & 399 & 6 & 49 & 454 \\
\hline 6 & 203 & 3 & 206 & 63 & 5 & 68 & 103 & 45 & 148 & 369 & 5 & 48 & 422 \\
\hline 7 & 213 & 3 & 216 & 61 & 4 & 65 & 104 & 46 & 150 & 378 & 4 & 49 & 431 \\
\hline 8 & 211 & 3 & 214 & 58 & 4 & 62 & 100 & 44 & 144 & 369 & 4 & 47 & 420 \\
\hline 9 & 209 & 3 & 212 & 58 & 5 & 63 & 101 & 43 & 144 & 368 & 5 & 46 & 419 \\
\hline 10 & 209 & 3 & 212 & 59 & 6 & 65 & 104 & 44 & 148 & 372 & 6 & 47 & 425 \\
\hline 11 & 197 & 3 & 200 & 56 & 5 & 61 & 106 & 44 & 150 & 359 & 5 & 47 & 411 \\
\hline 12 & 198 & 2 & 200 & 59 & 5 & 64 & 103 & 43 & 146 & 360 & 5 & 45 & 410 \\
\hline 13 & 190 & 2 & 192 & 60 & 5 & 65 & 106 & 45 & 151 & 356 & 5 & 47 & 408 \\
\hline 14 & 193 & 3 & 196 & 59 & 4 & 63 & 109 & 45 & 154 & 361 & 4 & 48 & 413 \\
\hline 15 & 205 & 2 & 207 & 56 & 5 & 61 & 105 & 42 & 147 & 366 & 5 & 44 & 415 \\
\hline Jumlah & 3213 & 44 & 3257 & 911 & 84 & 995 & 1602 & 674 & 2276 & 5726 & 84 & 718 & 6528 \\
\hline
\end{tabular}

Keterangan: $\mathrm{A}=$ Angket, $\mathrm{D}=$ Dokumentasi, dan $\mathrm{O}=$ Observasi 
Mendasarkan pada skor total dalam pelaksanaan pembelajaran geografi, untuk mengetahui kecenderungan pelaksanaan pembelajaran gografi oleh guru-guru di Kota Yogyakarta, perlu ditetapkan interval kategori frekuensi perolehan skor gabungan kecenderungan pelaksanaan pembelajaran geografi. Hasil perhitungan kategorisasi proses pelaksanaan pembelajaran geografi oleh guru di Kota Yogyakarta disajikan pada Tabel 7.

\section{Tabel 7. Distribusi Frekuensi Perolehan Skor Gabungan Kecenderungan Pelaksanaan Pembelajaran Geografi}

\begin{tabular}{ccccc}
\hline No. & Interval & Kategori & Frekuensi & Frekuensi Relatif (\%) \\
\hline 1. & $>513$ & Sangat Baik & 0 & 0 \\
2. & $395-513$ & Baik & 15 & 100 \\
3. & $276,5-394,9$ & Kurang Baik & 0 & 0 \\
4. & $<276,5$ & Tidak Baik & 0 & 0 \\
& Jumlah & & 15 & 10 \\
\hline
\end{tabular}

Tabel 7 menyajikan data tentang kecenderungan kategorisasi proses pelaksanaan pembelajaran geografi oleh guru di Kota Yogyakarta. Berdasarkan perhitungan tersebut, diperoleh data bahwa semua guru geografi melaksanakan pembelajaran geografi secara baik.

\section{PEMBAHASAN}

\section{Program Pembelajaran Geografi SMA} di Kota Yogyakarta

Hasil temuan penelitian menunjukkan bahwa program pembelajaran geografi SMA di Kota Yogyakarta dilaksanakan dengan baik secara lengkap, yang meliputi tujuan pendidikan satuan pendidikan, struktur dan muatan kurikulum, kalender pendidikan, silabus, dan rencana pelaksanaan pembelajaran, tetapi dengan penjelasan tidak terperinci. Melalui Tabel 3, dapat diketahui bahwa sebagian besar, yaitu $80 \%$ guru-guru geografi di Kota Yogyakarta memiliki pemahaman dan pe- laksanaan program pembelajaran dalam kategori baik, 6,67\% kategori sangat baik, serta $13,33 \%$ dalam kategori kurang baik. Hal ini menunjukkan bahwa secara umum guru-guru geografi SMA di Kota Yogyakarta termasuk dalam kategori baik dalam memahami dan melaksanakan program pembelajaran di sekolah yang meliputi indikator membuat perangkat pembelajaran, menentukan tujuan pendidikan satuan pendidikan, menentukan struktur dan muatan kurikulum, kalender pendidikan, silabus, serta merumuskan Rencana Pelaksanaan Pembelajaran (RPP) yang ditunjukkan oleh persentase terbesar perolehan skor tersebut. Sementara itu, hasil penelitian variabel program pembelajaran dari angket maupun dokumentasi dapat diketahui bahwa program pembelajaran yang selama ini berlangsung dan diterapkan pada mata pelajaran geografi sudah 
sesuai dengan harapan Kurikulum Tingkat Satuan Pendidikan (KTSP).

\section{Sistematika Proses Pembelajaran Geografi di Kota Yogyakarta}

Hasil penelitian mengenai variabel sistematika pembelajaran menunjukkan bahwa guru geografi di Kota Yogyakarta telah memahami dan melaksanakan proses pembelajaran yang dilakukan secara bertahap dan sistematis mulai dari pendahuluan, kegiatan inti, dan penutup. Mulai dari yang mudah sampai sulit, dari ringan sampai ke berat, dari rendah sampai ke tinggi. Hal ini terlihat dari data hasil penelitian menggunakan teknik pengumpulan data berupa angket dan observasi. Sebagian besar guru geografi di Kota Yogyakarta, yaitu $80 \%$ melaksanakan dan memahami sistematika pembelajaran dalam kategori baik, meskipun 20\% dalam kategori kurang baik. Hal ini menunjukkan bahwa secara umum pelaksanaan sistematika pembelajaran oleh guru-guru geografi di Kota Yogyakarta termasuk dalam kategori baik. Artinya, proses pembelajaran dilakukan secara bertahap dan sistematis mulai dari pendahuluan, kegiatan inti, dan penutup. Mulai dari yang mudah sampai sulit, dari ringan sampai ke berat, dari rendah sampai ke tinggi tetapi salah satu tahapan diabaikan.

\section{Penilaian Pembelajaran Geografi di Kota Yogyakarta}

Data hasil penelitian mengenai penilaian pembelajaran oleh guru sesuai Permendiknas No. 20/2007, yaitu berkaitan dengan prinsip, teknik, instrumen, dan mekansime atau prosedur penilaian serta pelaksanaannya diperoleh data bahwa sebagian besar guru geografi sudah menerapkan secara baik. Hal ini terungkap dari hasil analisis distribusi skor kategori total penilaian. Semua responden (100\%) sudah melaksanakan penilaian sesuai Permendiknas No.20/2007 dengan kategori baik. Hasil ini setidaknya memberikan gambaran pelaksanan penilaian untuk guru geografi di Kota Yogyakarta yang berjumlah sekitar 56 guru yang tersebar ke dalam 11 SMA Negeri dan 41 SMA Swasta.

Secara umum guru-guru geografi SMA di Kota Yogyakarta menunjukkan kecenderungan memahami dan melaksanakan prinsip-prinp penilaian secara baik. Prinsip penilaian sesuai Permendiknas No. 20/2007 meliputi indikator kesahihan, objektif, adil, terpadu, terbuka, menyeluruh dan berkesinambungan, sistematis, beracuan kriteria, serta akuntabel. Kesahihan penilaian didasarkan pada data yang mencerminkan kemampuan yang diukur. Objektifitas didasarkan pada prosedur dan kriteria yang jelas, tidak dipengaruhi subjektivitas penilai. Prinsip keadilan tidak menguntungkan atau merugikan peserta didik karena berkebutuhan khusus serta perbedaan latar belakang agama suku, budaya, adat istiadat, status sosial ekonomi, dan gender. Keterpaduan penilaian, yaitu tak terpisahkan dari kegiatan pembelajaran. Keterbukaan ditunjukkan oleh prosedur penilaian, kriteria penilaian, dan dasar pengambilan keputusan dapat diketahui oleh pihak yang berkepentingan. Menyeluruh dan berkesinambungan artinya penilaian oleh pendidik mencakup 
semua aspek kompetensi dengan menggunakan berbagai teknik penilaian yang sesuai untuk memantau perkembangan kemampuan peserta didik. Sistematis merupakan prinsip penilaian yang dilakukan secara berencana dan bertahap dengan mengikuti langkahlangkah baku. Beracuan kriteria yaitu penilaian didasarkan pada ukuran pencapaian kompetensi yang ditetapkan. Akuntabel yaitu penilaian dapat dipertanggungjawabkan, baik dari segi teknik, prosedur, maupun hasilnya.

Teknik penilaian pembelajaran oleh guru-guru geografi di Kota Yogyakarta dilakukan secara baik. Sesuai Permendiknas No. 20/2007 teknik penilaian meliputi indikator tes, observasi, penugasan, dan bentuk lain. Penilaian hasil belajar oleh guru geografi menggunakan berbagai teknik penilaian berupa tes, observasi, penugasan perseorangan atau kelompok, dan bentuk lain yang sesuai dengan karakteristik kompetensi dan tingkat perkembangan peserta didik. Hasil penelitian menunjukkan bahwa teknik penilaian yang paling banyak digunakan dalam pembelajaran geografi berupa tes dengan pemahaman yang sangat baik, diikuti oleh penugasan, bentuk-bentuk lain dan observasi.

Data hasil penelitian berkaitan dengan instrumen penilaian yang dibuat oleh guru geografi SMA di Kota Yogyakarta menggambarkan bahwa secara umum guru-guru geografi di Kota Yogyakarta dapat memahami dan melaksanakan instrumen penilaian secara baik. Sesuai Permendiknas No. 20/2007, instrumen penilaian meliputi indikator substansi, konstruksi, dan bahasa. Sub- stansi adalah merepresentasikan kompetensi yang dinilai. Konstruksi adalah memenuhi persyaratan teknis sesuai dengan bentuk instrumen yang digunakan, dan bahasa yaitu menggunakan bahasa yang baik dan benar serta komunikatif sesuai dengan taraf perkembangan peserta didik.

Berkaitan dengan mekanisme penilaian, hasil penelitian menunjukkan bahwa secara umum guru-guru geografi di Kota Yogyakarta dapat memahami dan melaksanakan mekanisme penilaian dengan baik. Mekansime penilaian sesuai Permendiknas No. 20/ 2007 meliputi 2 indikator, yaitu perancangan strategi dan ulangan. Perancangan strategi penilaian oleh pendidik dilakukan pada saat penyusunan silabus yang penjabarannya merupakan bagian dari rencana pelaksanaan pembelajaran (RPP). Ulangan tengah semester, ulangan akhir semester, dan ulangan kenaikan kelas dilakukan oleh pendidik di bawah koordinasi satuan pendidikan.

Hasil analisis statistik variabel pelaksanaan penilaian pembelajaran geografi menunjukkan bahwa guru-guru geografi di Kota Yogyakarta memahami dan melaksanakan penilaian dengan baik. Sesuai Permendiknas No. 20/2007, pelaksanaan penilaian meliputi sembilan kegiatan, yaitu: (1) menginformasikan silabus pada awal semester; (2) mengembangkan indikator pencapaian kompetensi dasar dan memilih teknik penilaian; (3) mengembangkan instrumen dan pedoman penilaian; (4) melaksanakan tes, pengamatan, penugasan, dan/atau bentuk lain; (5) mengolah hasil penilaian; (6) mengembalikan ha- 
sil penilaian; (7) memanfaatkan hasil penilaian; (8) melaporkan hasil penilaian kepada pimpinan; (9) dan melaporkan hasil penilaian akhlak kepada guru pendidikan agama dan kepada guru pendidikan kewarganegaraan.

\section{PENUTUP}

Implementasi KTSP pada pembelajaran geografi SMA di Kota Yogyakarta ditinjau dari dimensi guru yang meliputi: program pembelajaran, sistematika pelaksanaan pembelajaran, serta pelaksanaan penilaian hasil belajar termasuk dalam kategori baik.

Perangkat pembelajaran geografi telah dibuat dan dilaksanakan secara lengkap, meliputi tujuan pendidikan satuan pendidikan, struktur dan muatan kurikulum, kalender pendidikan, silabus, dan rencana pelaksanaan pembelajaran, tetapi tidak dijelaskan secara terperinci. Sistematika pembelajaran geografi di Kota Yogyakarta telah dilakukan secara bertahap dan sistematis mulai dari pendahuluan, kegiatan inti, dan penutup, tetapi sering salah satu tahapan tidak dilaksanakan. Guru geografi di Kota Yogyakarta telah melakukan penilaian sesuai ketentuan Permendiknas No. 20/2007 yang meliputi sub variabel prinsip, teknik, instrumen, mekanisme dan pelaksanaan penilaian, meskipun kadang-kadang salah satu sub variabel tidak dilaksanakan.

\section{UCAPAN TERIMA KASIH}

Penelitian ini tidak lepas dari bantuan berbagai pihak, baik secara moril, tenaga, waktu maupun materil. Oleh Karena itu, kami mengucapkan terima kasih kepada:
- Universitas Negeri Yogyakarta, terutama Fakultas Ilmu Sosial dan Ekonomi yang telah memberikan kesempatan bagi peneliti untuk melaksanakan penelitian;

- Pemerintah Provinsi DIY, terutama pemerintah Kota Yogyakarta atas izin yang telah diberikan;

- Redaktur dan reviewer jurnal Cakrawala Pendidikan yang telah memuat hasil penelitian ini;

- Semua pihak yang telah terlibat dalam penelitian ini.

\section{DAFTAR PUSTAKA}

Badan Standar Nasional Pendidikan. 2003. Undang-undang Nomor 20 Tahun 2003 tentang Sistem Pendidikan Nasional. Jakarta: Sekretariat Negara. 2006. Panduan Penyusunan Kurikulum Tingkat Satuan Pendidikan Jenjang Pendidikan Dasar dan Menengah. Jakarta: BSNP.

. Peraturan Menteri Pendidikan Nasional No. 22 Tahun 2006 tentang Standar Isi.

. Peraturan Menteri Pendidikan Nasional No. 23 Tahun 2006 tentang Standar Kompetensi Lulusan.

. Peraturan Menteri Pendidikan Nasional No. 20 Tahun 2007 tentang Standar Penilaian Pendidikan.

Brinkerhoff, R.D., Brethower, D.M., Hluchyj, T, et al. 1983. Program 
Evaluasion a Practitioner's Guide for Trainers and Educator. Western Michigan: Klower-nijhoff Publishing.

Departemen Pendidikan Nasional. 2005. Peraturan Pemerintah. No 19 Tahun 2005. tentang Standar Nasional Pendidikan.

Doreen, Massey. 2010. "'Is The World Really Shrinking?". tersedia di http://www.rgs.org/GeographyToday What+is+geography.htm. Diakses pada tanggal 23 Oktober 2007.

Badrussalam, Dudu. 2007. "Problematika Kebijakan Kurikulum Pendidikan". [Online] Tersedia di http://pendidikan-network.com. Diakses pada tanggal 23 Oktober 2007.
Kaufman, R. \& Susan, Thomas. 1980. Evaluation without Fear. New York: New View Point.

Sanjaya, Wina. 2009. Perencanaan dan Desain Sistem Pembelajaran. Jakarta: Kencana Prenada Media Group.

Stufflebeam, D.L. \& Shinkfield, A.J. 1985. Systematic Evaluation: a Instructional Guide to Theory \& Practice. Boston: Klower-nijhoff publishig.

Worthen R. Blaine \& Sanders R.J. 1981. Educational Evaluation: Theory and Practice. California: Wadsworth Publishing Company. Inc. 